\title{
PIOTR LEWANDOWSKI
}

\section{Aborcja w perspektywie kanonicznoprawnej. Zaciągnięcie i zwolnienie z ekskomuniki}

Ochrona ludzkiego życia i przerywania ciąży jest przedmiotem ożywionych debat społeczno-politycznych w zakresie stanowienia prawa. Zwolennicy i przeciwnicy szukają różnych argumentów na poparcie swoich tez. Tymczasem Kościół katolicki chroni życie ludzkie od chwili jego poczęcia do naturalnej śmierci. Pozbawienie życia niewinnej istoty ludzkiej skutkuje karą ekskomuniki wiążącej mocą samego prawa w chwili popełnienia niniejszego czynu.

Problematyka artykułu sprowadza się do analizy przestępstwa aborcji w perspektywie kanonicznoprawnej, ukazania czynników i okoliczności wpływających na zaciągnięcie i zwolnienie z powyższej kary, która ma na celu powrót sprawcy do korzystania z dóbr przysługujących wszystkim wiernym.

\section{Zarys zagadnienia w świetle wybranych dokumentów Kościoła katolickiego}

Aborcja, czyli zabieg mający na celu przerwanie ludzkiego życia w okresie płodowym $^{1}$, jest przedmiotem licznych dyskusji o charakterze etyczno-moralnym oraz prawnym ${ }^{2}$.

Piotr L E W A N D O W S K I, ks. dr prawa kanonicznego, adiunkt w Zakładzie Teologii Pastoralnej i Prawa Kanonicznego, Wydział Teologiczny Uniwersytetu im. Adama Mickiewicza w Poznaniu; audytor i sędzia w Trybunale Metropolitalnym w Gnieźnie, e-mail: piolew1@amu.edu.pl

${ }^{1}$ We współczesnej medycynie istnieje wiele metod urzeczywistnienia aborcji. Wyróżnia się kilka grup: $1^{\circ}$ inwazja do macicy przez drogi rodne (np. metody interrupcji, jak tyżeczkowanie $i$ wysysanie); $2^{\circ}$ zastosowanie środków farmakologicznych lub chemicznych zabijających dziecko $w$ stadium wczesnoembrionalnym (wktadki wewnatrzmaciczne, środki hormonalne, pigutka 486, postinor, metody immunologiczne) lub płodowym (np. zatrucie roztworem soli czy wywołanie poro- 
Prawo do życia stanowi fundament innych praw człowieka, $\mathrm{z}$ tego powodu wymaga ochrony prawnej. Tę ochronę zapewnia państwo we własnym porządku prawnym, mimo silnych tendencji dążących do osłabienia i zrelatywizowania tego prawa $^{3}$. $Z$ pomocą przychodzi etyka chrześcijańska potępiająca przerywanie ciąży. Przedstawiciele nurtów pro-life zabiegają o ochronę życia poczętego na forum państwowym ${ }^{4}$.

Urząd Nauczycielski Kościoła katolickiego wskazuje na nienaruszalne prawo do życia każdego człowieka od chwili jego poczęcia ${ }^{5}$. Bezpośrednie przerwanie ciaży, to znaczy zamierzone jako cel czy jako środek, jest zawsze poważnym nieładem moralnym, gdyż jest dobrowolnym zabójstwem niewinnej istoty ludz$k_{i e j}{ }^{6}$. Bez względu na motywy działania, żadne racje, jakkolwiek poważne i dramatyczne, nigdy nie moga usprawiedliwić umyślnego pozbawienia życia tejże istoty ${ }^{7}$.

Jan Paweł II stwierdził, że aborcja jest-niezależnie od tego, w jaki sposób zostaje dokonana - świadomym i bezpośrednim zabójstwem istoty ludzkiej w poczatkowym stadium jej życia, obejmujacym okres między poczęciem a narodzeniem ${ }^{8}$.

U podstaw nauczania Kościoła katolickiego leży godność osoby ludzkiej. Zatem każde przerwanie ciąży sprzeciwia się prawu osoby do dysponowania soba, podporzadkowuje poczęte życie ludzkim potrzebom lub dązeniom innych ludzi .

Nauczanie kościelne odsyła do naturalnego prawa moralnego jako do najwyższego i najświętszego ze wszystkich praw ludzkich, wpisanego przez Boga

du za pomoca prostaglandyn, po czym prowokowanie akcji porodowej w celu opróżnienia macicy); $3^{\circ}$ inwazja do macicy przez zastosowanie interwencji chirurgicznej (np. histerotomia). J. Kowalski: Aborcja. W: Encyklopedia bioetyki. Personalizm chrześcijański. Pod redakcja Andrzeja Muszali. Radom 2009 s. 55.

${ }^{2}$ Por. Kongregacja Nauki Wiary: Deklaracja o przerywaniu ciąży. AAS. R. 66: 1974 s. $730-747$.

${ }^{3}$ Por. P. Jaros: Prawne aspekty ochrony dziecka przed urodzeniem. W: Aborcja. Przyczyny, następstwa, terapia. Pod redakcja Bogdana Chazana i Witolda Simona. Wrocław 2009 s. 15-16.

${ }^{4}$ Por. T. Slipko: Współczesna debata nad ustawa o aborcji. W: Aborcja. Spojrzenie filozoficzne, teologiczne, historyczne i prawne. Pod redakcja Tadeusza Ślipko, Marka Starowieyskiego, Andrzeja Muszali. Kraków 2010 s. 53.

${ }^{5}$ Por. Kongregacja Nauki Wiary: Donum vitae. Instrukcja o szacunku dla rodzącego się życia ludzkiego i o godności jego przekazywania (22 lutego 1987). AAS. R. 80: 1988 s. 76-77; Sobór Watykański II: Gaudium et spes, Konstytucja duszpasterska o Kościele w świecie współczesnym (7 grudnia 1965). AAS. 58: 1966 s. 1072.

${ }^{6}$ Jan Paweł II: Encyklika Evangelium vitae. nr 62. AAS. R. 87: 1995 s. 471-472.

${ }^{7}$ Tamże, nr 58

${ }^{8}$ Tamże.

${ }^{9}$ J. Kowalski: Aborcja, dz. cyt., s 57. 
w człowieka. Z nim wiąże się poszanowanie praw człowieka, wśród których na pierwszym miejscu znajduje się prawo do życia ${ }^{10}$.

Naruszenie prawa do życia, a zwłaszcza przerwanie ciąży należy do przestępstw szczególnie ciężkich, pociąga za sobą sankcje karne, które mają na celu doprowadzenie do poprawy sprawcy przestępstwa i ewentualnych współsprawców, a w dalszej perspektywie ich zbawienie ${ }^{11}$. Oznacza to, że kara ma uświadomić winowajcy powage popetnionego grzechu ${ }^{12}$.

\section{Sankcje karne}

Kanon 1398 Kodeksu Prawa Kanonicznego stwierdza: Kto powoduje przerwanie ciąży, po zaistnieniu skutku, podlega ekskomunice wiążacej moca samego prawa $^{13}$. Oznacza to, że w momencie popełnienia aborcji automatycznie dochodzi do zaciągnięcia tejże kary. Jeśli jednak popełnienie aborcji stałoby się faktem powszechnie znanym, to wówczas kompetentna władza kościelna może wymierzyć lub deklarować zaciągnięcie rozpatrywanej ekskomuniki wyrokiem sądowym bądź dekretem administracyjnym ${ }^{14}$. Możliwość wymierzenia lub deklarowania ekskomuniki z tytułu analizowanego przestępstwa ulega jednak przedawnieniu po upływie pięciu lat ${ }^{15}$.

Papieska Rada ds. Autentycznej Interpretacji Kodeksu Prawa Kanonicznego stwierdziła, że aborcja jest dobrowolnym pozbawieniem życia niedojrzałego płodu, dokonane jakimkolwiek sposobem bez względu na czas który upłynął od chwili poczęcia ${ }^{16}$.

Przyjmuje się, że mamy do czynienia z niedojrzałym płodem w okresie 180 dni od chwili poczęcia ${ }^{17}$. Na tym stadium rozwoju płód nie jest jeszcze zdolny do

${ }^{10}$ Tamże, s. 56-57.

11 Por. E. Martinelli: L'azione penale nell'ordinamento canonico. Uno studio di diritto comparato. Torino 2011 s. 39-41.

${ }^{12}$ Jan Paweł II: Encyklika Evangelium vitae, $\mathrm{nr} 25$.

${ }^{13}$ Ioannes Paulus II: Codex Iuris Canonici. AAS. R. 75 II: 1983 s. 242. Tekst polski: Kodeks Prawa Kanonicznego. Komentarz. Kraków 2011 s. 1044.

${ }^{14}$ Por. P. M. Gajda: Sankcje karne w Kościele w świetle Kodeksu Prawa Kanonicznego Jana Pawta II oraz późniejszych zmian i uzupetnień. Studium kanoniczno-pastoralne. Tarnów 2008 s. 176.

${ }^{15}$ Por. Ioannes Paulus II: Codex Iuris Canonici. can. $1362 \S 1,2^{\circ}$ s. 237. Tekst polski: Kodeks Prawa Kanonicznego. Komentarz, dz. cyt., s. 1022.

${ }^{16}$ Pontificia Commissio Codicis Iuris Canonici Authentice Interpretando: Odpowiedź zatwierdzona przez Papieża Jana Pawła II dnia 23 maja 1988 roku. AAS. R. 80: 1988 s. 1818-1819.

${ }^{17}$ Por. V. De Paolis, D. Cito: Le sanzioni nella Chiesa. Città del Vaticano 2000 s. 365. 
życia poza organizmem matki ${ }^{18}$. Jeśli do pozbawienia życia doszłoby po upływie tego okresu, to wówczas ma miejsce zabicie dojrzałego już płodu ${ }^{19}$.

Jeśli nie było bezpośredniego zamiaru przerwania ciąży, a do utraty płodu doszło $\mathrm{z}$ winy nieumyślnej z jakiejkolwiek przyczyny, np. poronienia, to nie dochodzi do popełnienia przestępstwa ${ }^{20}$.

Do przerwania ciąży dochodzi zatem po zaistnieniu skutku, stąd potrzeba pewności moralnej, czy rzeczywiście doszło do jej popełnienia. W razie jakiejkolwiek wątpliwości nie dochodzi do naruszenia prawa ${ }^{21}$.

Przyjęcie tabletki o działaniu aborcyjnym dzień po niekoniecznie pociąga za sobą aborcję z tego względu, że jest ona uwarunkowana uprzednim zapłodnieniem. Na tym etapie rozwoju embrionu nie można ustalić bez odpowiedniego badania, czy doszło rzeczywiście do zapłodnienia, a zatem gdyby ewentualnie została przerwana ciąża, to sprawca czynu nie zostaje pociągnięty do odpowiedzialności karnej w związku z brakiem pewności co do jego popełnienia ${ }^{22}$.

\section{Ekskomunika wiążąca mocą samego prawa}

Ekskomunika należy do kategorii kar poprawczych. Kary tego typu nakładane są na ochrzczonych w Kościele katolickim lub do niego przyjętych ${ }^{23}$, którzy popełnili przestępstwo i trwają w uporze $\mathrm{e}^{24}$. Tym samym kara pozbawia możliwości korzystania $\mathrm{z}$ dóbr przysługujących wszystkim wiernym, którymi Kościół dysponuje do osiągnięcia zbawienia oraz praw wynikających $\mathrm{z}$ sakramentu chrztu $^{25}$. Przez przestępstwo przerwania ciąży sprawca nie rozwiązuje więzów wiary, sakramentów i zwierzchnictwa kościelnego, jednakże podlega zakazowi przyjmowania wszystkich sakramentów. Tenże zakaz nie oznacza wyłączenia wiernego z pełnej wspólnoty z Kościołem ${ }^{26}$.

Pomimo zakazu przyjmowania sakramentów przez ekskomunikowanych, gdyby doszło do ich przyjęcia, to przyjmują je ważnie, jednakże niegodziwie.

\footnotetext{
${ }^{18}$ Por. L. Chiappetta: Il Codice di Diritto Canonico. Commento giuridico - pastorale. Roma 1996 vol. II s. 688.

${ }^{19}$ Por. V. De Paolis, D. Cito: Le sanzioni nella Chiesa. dz. cyt. s. 365. Zob. V. De Paolis: Aborto. W: Nuovo dizionario di diritto canonico. Red. C.C. Salvador, V. De Paolis, G. Ghirlanda. Milano 1996 s. 1.

${ }^{20}$ Por. J. Syryjczyk: Kanoniczne prawo karne. Część szczególna. Warszawa 2003 s. 179.

${ }^{21}$ Por. J. Sanchis: L'aborto procurato: aspetti canonistici. „Ius Ecclesiae”. 2: 1989 s. 672.

${ }^{22}$ Por. tamże.

${ }^{23}$ Por. Ioannes Paulus II: Codex Iuris Canonici. can. 11. Tekst polski: Kodeks Prawa Kanonicznego. Komentarz, dz. cyt., s. 73.

${ }^{24}$ Por. tamże can. 1347 § 1 s. 234 . Tekst polski: s. 1012.

${ }^{25}$ Por. J. Syryjczyk: Sankcje w Kościele: część ogólna. Komentarz. Warszawa 2008 s. 215.

${ }^{26}$ Por. J. Syryjczyk: Kara ekskomuniki a petna wspólnota kościelna wedtug Kodeksu Prawa Kanonicznego z 1983 r. „Prawo kanoniczne”. R. 33: 1990 nr 3-4 s. 185.
} 
Ekskomunikowany jedynie w sakramencie pokuty i pojednania nie otrzyma ważnego rozgrzeszenia, jeśli uprzednio nie zostanie zwolniony z kary. Taka sytuacja będzie miała miejsce, jeśli spowiednik nie posiada władzy do zwalniania z ekskomuniki, po której dochodzi do rozgrzesznia penitenta (zob. rozdz. VI) ${ }^{27}$.

Obowiązek zachowania ekskomuniki wiążącej mocą samego prawa może zostać zawieszony w całości lub w części, jeśli nie jest ona powszechnie znana w miejscu przebywania sprawcy, ze względu na niebezpieczeństwo poważnego zgorszenia lub zniesławienia ${ }^{28}$.

Zaciągnięcie ekskomuniki wiążącej mocą samego prawa za popełnienie przestępstwa aborcji nie upoważnia do wniesienia apelacji, chyba że niniejsza ekskomunika została wymierzona lub deklarowana wyrokiem sądowym czy dekretem administracyjnym ${ }^{29}$.

\section{Sprawca oraz wspólnicy przestępstwa}

Odpowiedzialności karnej podlega w pierwszym rzędzie matka, która świadomie i dobrowolnie podjęła działania zmierzające do usunięcia ciąży za pośrednictwem jednej $\mathrm{z}$ metod wymienionych $\mathrm{w}$ trzecim przypisie. Do zaciągnięcia niniejszej ekskomuniki dochodzi tylko wtedy, gdy jej czyn był w pełni poczytalny $^{30}$.

KPK w kanonie 1329 § 2 określa współudział w popełnieniu przestępstwa: Karze wiązacej moca samego prawa dołaczonej do przestępstwa podlegaja wspólnicy nie wymienieni $w$ ustawie lub nakazie, jeśli bez ich udziału przestępstwo nie byloby dokonane, a kara jest tej natury, że może ich dotyczyćc ${ }^{31}$. Współudział w popełnieniu przestępstwa aborcji może być całkowity lub częściowy ${ }^{32}$. Toteż wszyscy, którzy współuczestniczyli moralnie lub fizycznie w tym prze-

${ }^{27}$ Por. J. Syryjczyk: Sankcje w Kościele: część ogólna. Komentarz. dz. cyt. s 220.

${ }^{28}$ Por. Ioannes Paulus II: Codex Iuris Canonici. can. $1352 \S 2$ s. 235. Tekst polski: Kodeks Prawa Kanonicznego. Komentarz. dz. cyt. s. 1014.

${ }^{29}$ Por. tamże. Tekst polski: Kodeks Prawa Kanonicznego. Komentarz, dz. cyt., s. 1015.

${ }^{30}$ Por. Ioannes Paulus II: Codex Iuris Canonici. can. 1321 s. 228. Tekst polski: Kodeks Prawa Kanonicznego. Komentarz. dz. cyt. s. 992. Zob. P. Erdö: Il peccato e il delitto. La relazione tra due concetti fondamentali alla luce del diritto canonico. Milano 2014 s. 87-90.

31 Tamże. can. $1329 \S 2$ s. 230. Tekst polski: Kodeks Prawa Kanonicznego. Komentarz, dz. cyt., s. 1000

${ }^{32}$ Współudział całkowity zachodzi, gdy dwie lub więcej osób współdziała fizycznie w jego dokonaniu. Natomiast koncepcja współudziału częściowego zachodzi po stronie zaangażowanych w dokonanie przestępstwa za pomocą jakiegokolwiek sposobu. Współudział częściowy o charakterze moralnym sprowadza się do zlecenia, nakazu, podżegania, szantażu czy przymusu. We wspótudziale częściowym wyróżnia się sprawce głównego (którym jest wykonawca, a także zleceniodawca lub wydający nakaz) i pozostałych wspóluczestników, czyli wspólników przestępstwa. J. Syryjczyk: Sankcje w Kościele: część ogólna. Komentarz, dz. cyt., s. 194. Zob. J. Syryjczyk: Kanoniczne prawo karne. Część szczególna, dz. cyt., s. 179. 
stępstwie, za sprawą wszelkiego rodzaju przymusu, szantażu, podżegania czy wywierania nacisku zaciągają ekskomunikę wiążącą mocą samego prawa ${ }^{33}$.

Powyższą ekskomunikę zaciągają zatem wszyscy, którzy świadomie, dobrowolnie i bezpośrednio dokonują zabiegu przerwania ciąży przez zastosowanie odpowiednich środków, bez względu na to, czy dopuścili się popełnienia przestępstwa z własnej inicjatywy, czy na zlecenie innych osób. Do tej kategorii zalicza się wspólników koniecznych, którzy przyczynili się usunięcia płodu z łona matki ${ }^{34}$. A zatem karę zaciąga ten, kto fizycznie jest wykonawcą aborcji bądź współuczestniczy w jej urzeczywistnieniu. Powyższą karę tak samo zaciągają odpowiedzialni moralnie za namawianie do aborcji, ojciec płodu lub rodzice matki ${ }^{35}$.

Aby doszło do popełnienia przestępstwa aborcji z winy umyślnej karanej ekskomuniką, wymagana jest świadomość nie tylko bezprawności czynu, ale także świadomość przestępczości, tj. znajomość przewidzianej $w$ ustawie kary poprawczej $^{36}$.

\section{Czynniki lagodzące lub zwalniające z kary}

Do popełnienia przestępstwa dochodzi z winy umyślnej lub nieumyślnej. Zasadniczo odpowiedzialności karnej podlegają przestępstwa umyślne. Jeśli dochodzi do popełnienia przestępstwa nieumyślnie, wymierza się karę tylko wtedy, gdy ustawa zastrzega inaczej ${ }^{37}$.

Zaciągnięcie lub deklarowanie ekskomuniki za przerwanie ciąży może być uwarunkowane ewentualnymi okolicznościami łagodzącymi lub zwalniającymi ${ }^{38}$. Wystąpienie tych czynników, pomimo popełnienia grzechu ciężkiego, nie przyczynia się zaciągnięcia ekskomuniki ${ }^{39}$.

Wobec tego nie podlega żadnej karze ten, kto: nie ukończył jeszcze szesnastego roku życia; doprowadził do przerwania ciąży z powodu niezawinionej nieznajomości ustawy karnej lub kary bądź poprzez nieuwagę lub błąd; działał pod wpływem przymusu fizycznego lub na skutek przypadku, którego nie mógł przewidzieć lub przewidzianemu zapobiec; działał pod wpływem względnie

33 Por. Tamże, s. 179.

34 Por. P.M. Gajda, dz. cyt., s. 96-97.

35 Por. D. Milani: L'inizio della vita nel diritto canonico W: Intorno alla vita che nasce. Diritto ebraico, canonico e islamico a confronto. Red. D. Atighetchi, D. Milani, A. M. Rabello. Torino 2013 s. 178.

${ }^{36}$ J. Syryjczyk: Sankcje w Kościele: część ogólna. Komentarz. dz. cyt. s. 113-114.

${ }^{37}$ Por. Ioannes Paulus II: Codex Iuris Canonici. can. 1321. Tekst polski: Kodeks Prawa Kanonicznego. Komentarz, dz. cyt., s. 992.

38 Tamże can. 1323-24 s. 229. Tekst polski: s. 994-996.

${ }^{39}$ Por. V. De Paolis, D. Cito: Le sanzioni nella Chiesa, dz. cyt., s. 366. 
ciężkiej bojaźni albo z konieczności lub wskutek wielkiej niedogodności; działał w obronie własnej, zachowując należny umiar; nie posiadał używania rozumu wskutek zawinionego nadużywania alkoholu lub podobnego zaburzenia umysłowego; sądził bez winy, że zachodzi ciężka bojaźń, konieczność, niedogodność czy obrona własna ${ }^{40}$.

Kara zostaje złagodzona lub zastąpiona pokutą, jeśli przerwanie ciąży zostało popełnione przez tego, kto: używał rozumu w stopniu ograniczonym; wskutek zawinionego nadużycia alkoholu lub podobnego zaburzenia umysłowego nie posiadał używania rozumu; był w stanie poważnego wzburzenia uczuciowego; jest małoletnim, który ukończył szesnasty rok życia; był przymuszony względnie ciężką bojaźnią lub działał z konieczności lub wielkiej niedogodności; działał w obronie własnej bez zachowania koniecznego umiaru; prowadził działania przeciwko poważnie i niesłusznie prowokującemu; z własnej winy trwał w błędzie, co do ciężkiej bojaźni lub obrony własnej; bez własnej winy nie posiadał wiedzy względem kary dołączonej do ustawy; nie był w pełni poczytalny ${ }^{41}$.

\section{Zwolnienie z ekskomuniki w sytuacjach zwyczajnych}

Nie można udzielić zwolnienia z ekskomuniki zaciągniętej za przerwanie ciąży, jeśli sprawca nie odstąpił od uporu ${ }^{42}$. Przyjmuje się, że odstąpił od uporu ten, kto faktycznie wyrazit żal z powodu popetnienia przestępstwa, a ponadto odpowiednio naprawit szkody i zgorszenie lub przynajmniej poważnie to przy$r z e k t^{43}$. W ten sposób odstępującemu od uporu nie odmawia się zwolnienia ${ }^{44}$.

Zwolnienie $\mathrm{z}$ analizowanej kary dochodzi do skutku drogą absolucji, jednak nie wszyscy spowiednicy posiadają władzę zwalniania $z$ tej kary w sytuacjach zwyczajnych. Prawodawca przyznaje taką władzę ordynariuszowi w stosunku do własnych podwładnych oraz tych, którzy przebywaja na jego terytorium lub na nim dopuścili się przestępstwa, a także każdemu biskupi $w$ akcie sakramentalnej spowiedzi ${ }^{45}$.

Jeśli przerwanie ciąży stało się powszechnie znane, a właściwy ordynariusz wszcząt postępowanie sadowe $w$ celu wymierzenia lub deklarowania kary, badź

\footnotetext{
${ }^{40}$ Por. Ioannes Paulus II: Codex Iuris Canonici. can. 1323 s. 229. Tekst polski: Kodeks Prawa Kanonicznego. Komentarz, dz. cyt., s. 994.

${ }^{41}$ Por. tamże can. 1324. Tekst polski: s. 995-996.

${ }^{42}$ Por. tamże can. 1358 § 1. Tekst polski: s. 1019-1020.

${ }^{43}$ Tamże can. 1347 § 2. Tekst polski: s. 1012.

${ }^{44}$ Por. tamże can. 1358 § 1 . Tekst polski: s. 1020.

${ }^{45}$ Tamże. can. 1355 § 2. Tekst polski: s. 1016.
} 
sam ja wymierzyt lub deklarowat dekretem ${ }^{46}$, to na nim lub na innym ordynariu$\mathrm{szu}^{47}$ spoczywa możliwość zwolnienia z ekskomuniki ${ }^{48}$.

Władzę zwyczajną zwalniania z ekskomuniki wiążącej mocą samego prawa $\mathrm{z}$ przestępstwa aborcji posiada również $\mathrm{w}$ zakresie sakramentalnym kanonik penitencjarz kościoła katedralnego bądź kościoła kolegiackiego ${ }^{49}$. Kompetencje kanonika penitencjarza do zwalniania $\mathrm{z}$ ekskomuniki nie dotyczą spraw, które zostały deklarowane wyrokiem sądowym lub dekretem administracyjnym ${ }^{50}$. Zakres władzy penitencjarza upoważnia go do zwalniania z zaciągniętej ekskomuniki, na terenie diecezji w której powierzono mu tenże urząd, zarówno diecezjan, jak i obcych. Jeśli przebywa poza diecezją, to jego władza zwalniania z ekskomuniki ulega ograniczeniu do wiernych diecezji, w której posługuje ${ }^{51}$.

Władzę zwalniania z ekskomuniki wiążącej mocą samego prawa zaciągniętej za przerwanie ciąży posiadają $\mathrm{w}$ zwyczajnych okolicznościach kapelani szpitala, więzienia i podróży morskiej. Mogą korzystać z tego uprawnienia tylko w miejscu sprawowania danego urzędu ${ }^{52}$.

Zwolnienie sprawcy lub współsprawcy przestępstwa aborcji z ekskomuniki wiążącej mocą samego prawa $\mathrm{w}$ zwyczajnych okolicznościach nie implikuje obowiązku odniesienia się do kompetentnego przełożonego po zwolnienie w zakresie zewnętrznym lub otrzymanie stosownych poleceń, tak jak w przypadku naglącym bądź w niebezpieczeństwie śmierci ${ }^{53}$.

\section{Przypadek naglący i niebezpieczeństwo śmierci}

$\mathrm{Z}$ mocy prawa upoważnia się spowiednika do zwolnienia $\mathrm{z}$ ekskomuniki wiążącej mocą samego prawa $\mathrm{w}$ niebezpieczeństwie śmierci i w przypadku naglącym $^{54}$. Przytoczone uprawnienie spowiednika nie dotyczy jednak ekskomuni-

46 Tamże.

47 Termin ordynariusz odnosi się do każdego, kto posiada władzę rządzenia w zakresie zewnętrznym, przynajmniej wykonawczą, niezależnie od tego, czy jest ona własna, czy tylko zastępcza. Do tej kategorii osób zalicza się między innymi: biskupa diecezjalnego oraz tych, którzy są - choćby tylko czasowo - przełożonymi Kościoła partykularnego oraz wikariusza generalnego i biskupiego. Por. tamże. can. $134 \S 1$. Tekst polski: s. 155.

${ }^{48}$ Por. tamże. can. $1355 \S 1$. Tekst polski: s. 1016.

${ }^{49}$ Por. tamże. can. $508 \S 1$. Tekst polski: s. 434.

${ }^{50}$ Por. M. Stokłosa: Uwolnienie z kar kościelnych w sakramencie pokuty. „Studia Redemptorystowskie". R. 2011 nr 9-10 s. 341.

${ }^{51}$ Por. tamże. can. $508 \S 1$. Tekst polski: s. 434.

52 Por. tamże. can. $566 \S 2$. Tekst polski: s. 477.

53 Por. M. Stokłosa: dz. cyt. s. 357.

${ }^{54}$ Kan. 1357 \& 1. Z zachowaniem przepisów kan. 508 i 976 z cenzury ekskomuniki lub interdyktu, wiążacej moca samego prawa, jeszcze niedeklarowanej, może $w$ zakresie wewnętrznym sakramentalnym zwolnić spowiednik, jeśli penitentowi jest trudno pozostawać w grzechu ciężkim przez czas konieczny do tego, aby zaradził kompetentny przełożony. 
ki już wymierzonej lub orzeczonej (deklarowanej) wyrokiem sądowym bądź dekretem administracyjnym. Ocena rozpatrywanych okoliczności należy do spowiednika ${ }^{55}$.

Kategoria naglącego przypadku nie odnosi się do niebezpieczeństwa zgorszenia lub zniesławienia sprawcy. W okolicznościach naglącego przypadku oraz niebezpieczeństwa śmierci spowiednik udzielający absolucji z ekskomuniki nakłada na penitenta obowiązek odwołania się w ciągu miesiąca do każdego biskupa, kanonika penitencjarza kościoła katedralnego lub kolegiackiego, którzy posiadają władzę zwalniania z ekskomuniki aborcji w sakramencie pokuty i pojednania. Taka możliwość istnieje również za pośrednictwem spowiednika. Odniesienie się do kompetentnego przełożonego lub kapłana posiadającego uprawnienia pociąga za sobą zastosowanie się do otrzymanych poleceń ${ }^{56}$. Analogiczne uprawnienia przysługują kapelanom szpitali, więzień lub podróżujących na morzu względem osób tam przebywających ${ }^{57}$.

Każdy kapłan, chociażby nie miat uprawnienia do spowiadania, ważnie $i$ godziwie rozgrzesza jakichkolwiek penitentów znajdujących się $w$ niebezpieczeństwie śmierci z wszelkich kar i grzechów ${ }^{58}$. Niebezpieczeństwo śmierci może być związane z chorobą, poważną operacją, kataklizmem, wojną, itp. Jeśli doszło do wymierzenia lub deklarowania ekskomuniki za przerwanie ciąży wyrokiem lub dekretem administracyjnym, to po ustaniu niebezpieczeństwa śmierci sprawca przestępstwa winien odnieść się w ciągu miesiąca do powyższej grupy uprawnionych do zwalniania z ekskomuniki, aby otrzymać właściwe polecenia. Niedopełnienie tej czynności prowadzi do ponownego popadnięcia w karę ekskomuni$\mathrm{ki}^{59}$.

§ 2. Udzielając zwolnienia spowiednik powinien nałożyć na penitenta obowiązek odniesienia się w ciagu miesiaca, pod groźba ponownego popadnięcia w karę, do kompetentnego przełożonego, badź do kapłana posiadajacego odpowiednie uprawnienia oraz zastosowania się do otrzymanych poleceń. Tymczasem spowiednik powinien natożyć odpowiednia pokute $i$ w razie potrzeby nakazać naprawienie zgorszenia $i$ wyrównanie wyrządzonej szkody. Odniesienia może dokonać także spowiednik bez podania nazwiska.

§ 3. Taki sam obowiązek odniesienia się z chwila wyzdrowienia mają ci, którzy zgodnie z kan. 976 zostali zwolnieni z cenzury wymierzonej lub deklarowanej albo zarezerwowanej Stolicy Apostolskiej. Jan Paweł II: Kodeks Prawa Kanonicznego. Komentarz, dz. cyt., s. 1018-1019.

${ }^{55}$ Por. J. Syryjczyk: Sankcje w Kościele: część ogólna. Komentarz, dz. cyt., s. 303-304.

${ }^{56}$ Por. Ioannes Paulus II: Codex Iuris Canonici. can. 1357 § 2. Tekst polski: Kodeks Prawa Kanonicznego. Komentarz, dz. cyt., s. 1018-1019.

${ }^{57}$ Por. J. Syryjczyk: Sankcje w Kościele: część ogólna. Komentarz, dz. cyt., s. 304.

${ }^{58}$ Ioannes Paulus II: Codex Iuris Canonici, dz. cyt., can. 976. Tekst polski: Kodeks Prawa Kanonicznego. Komentarz, dz. cyt., s. 733.

${ }^{59}$ Por. J. Syryjczyk: Sankcje w Kościele: część ogólna. Komentarz, dz. cyt., s. 307-308. 


\section{Prawo partykularne}

Poza normami wyżej wymienionymi, prawo powszechne przewiduje możliwość delegowania przez ordynariuszy i ordynariuszy miejsca zwyczajnej władzy wykonawczej w zakresie zwalniania z kar, zarówno na płaszczyźnie zewnętrznej, jak i na forum sakramentalnym. W ten sposób, ze względu na dobro duchowe wiernych, ordynariusze miejsca delegują ponadto innych spowiedników do zwalniania z ekskomuniki wiążącej mocą samego prawa za przerwanie ciąży, która nie została wymierzona lub orzeczona wyrokiem sądowym lub dekretem administracyjnym ${ }^{60}$.

Uchwała sesji plenarnej Konferencji Episkopatu Polski z dnia 29 marca 1984 roku podjęta celem ujednolicenia uprawnień na terenie Polski do rozgrzeszenia z ekskomuniki wiążącej mocą samego prawa, którą zaciągają dopuszczający się przerwania ciąży, zaleciła biskupom diecezjalnym, aby upoważnili w zakresie wewnętrznym sakramentalnym następujących kapłanów: księży dziekanów i wicedziekanów; proboszczów i administratorów parafii; wszystkich kapłanów spowiadających w kościołach katedralnych i sanktuariach wyznaczonych przez biskupa; przełożonych wyższych i przełożonych domów kleryckich instytutów życia konsekrowanego oraz kleryckich stowarzyszeń życia apostolskiego; wszystkich spowiedników: w czasie komunii wielkanocnej, rekolekcji i misji; w czasie wizytacji kanonicznych i odpustów parafialnych; przy spowiedzi narzeczonych, żołnierzy i więźniów; z okazji spowiedzi w szpitalach i chorych, którzy nie wychodzą z mieszkania oraz kobiet ciężarnych; przy spowiedzi generalnej przynajmniej z jednego roku ${ }^{61}$.

Niezależnie od norm prawa kanonicznego, zarówno powszechnego, jak i partykularnego, Stolica Apostolska udzieliła w przeszłości przewileju spowiednikom zakonów żebrzących, upoważniającego ich do udzielenia absolucji z ekskomuniki wiążącej mocą samego prawa za przestępstwo przerwania ciąży w każdej chwili bez względu na miejsce ${ }^{62}$.

\section{Postanowienia Roku Miłosierdzia}

Dnia 8 grudnia 2015 r. Papież Franciszek zainaugurował Jubileuszowy Rok Miłosierdzia, którego zakończenie przewidziano na 20 listopada 2016 r. Przesłaniem tego Jubileuszu jest spotkanie z miłosierdziem Boga. Papież upoważnił

\footnotetext{
${ }^{60}$ Por. Ioannes Paulus II: Codex Iuris Canonici, dz. cyt., can. 137 § 1, can. 1354-1356. Tekst polski: Kodeks Prawa Kanonicznego. Komentarz, dz. cyt., s. 159. 1015-1018.

${ }^{61}$ Por. J. Glemp: Dekret w sprawie upoważnienia do rozgrzeszenia z ekskomuniki latae sententiae z kan. 1398. „Wiadomości Archidiecezji Gnieźnieńskiej”. 5-7: 1984 s. 114-115.

${ }^{62}$ Por. E. McNamara: La facoltà di assolvere dalle censure. W: https://it.zenit.org/articles/lafacolta-di-assolvere-dalle-censure/ (dostęp: 11.06.2016).
} 
wszystkich kapłanów w tymże Roku do rozgrzeszenia z grzechu aborcji, mimo wszelkich przeciwnych rozporządzeń ${ }^{63}$.

\section{Formuła zwolnienia}

Obrzęd zwolnienia z ekskomuniki wiążącej mocą samego prawa z przestępstwa aborcji oraz rozgrzeszenie sakramentalne tego czynu w sakramencie pokuty i pojednania nie wymaga zmieniania formuły rozgrzeszenia, wystarczy jedynie, aby spowiednik miał intencję rozgrzeszenia $\mathrm{z}$ ekskomuniki. W innym układzie, zanim spowiednik rozgrzeszy penitenta może zwolnić z ekskomuniki słowami formuły przewidzianej poza sakramentem pokuty: $\mathrm{Na}$ mocy udzielonej mi władzy uwalniam ciebie z więzów ekskomuniki. W imię Ojca i Syna + i Ducha Świętego. Amen ${ }^{64}$.

\section{Zakończenie}

Pomimo że aborcja należy najcięższych przestępstw przeciwko życiu, które pociąga za sobą karę ekskomuniki, to Kościół, mając na względzie zbawienie sprawcy i koniecznych wspólników tego czynu, nadaje szerokiej grupie spowiedników właściwe uprawnienia do udzielenia absolucji z ekskomuniki wiążącej mocą samego prawa za popełnione przestępstwo. Poza tym wyznacza liczne miejsca, w których wierni mogą skorzystać ze zwolnienia z rozpatrywanej kary.

Analiza aborcji w kontekście przeżywanego Nadzwyczajnego Jubileuszu Miłosierdzia pozwala na głębsze doświadczenie przebaczenia i Miłosierdzia Bożego przez tych, którzy czują się zranieni czy odrzuceni, a za pośrednictwem Kościoła i jego szafarzy mogą wrócić na drogę nawrócenia.

${ }^{63}$ Dramat aborcji przeżywany jest przez niektóre osoby ze świadomościa powierzchowna, jakby niemal nie zdawaty sobie sprawy z tego, jak wielkim złem jest ten akt. Wiele innych natomiast, choć przeżywa ten moment jako porażkę, uważa, że nie maja innej drogi. Myślę w szczególności o wszystkich kobietach, które poddały się aborcji. (...) Przebaczenia Bożego nie można odmówić nikomu, kto żałuje, zwłaszcza jeśli ze szczerym sercem przystęuje do Sakramentu Spowiedzi, by pojednać się z Ojcem. Również z tego powodu postanowitem, mimo wszelkich przeciwnych rozporządzeń, upoważnić wszystkich kapłanów w Roku Jubileuszowym do rozgrzeszenia z grzechu aborcji osób, które jej dokonaty, żatuja tego z całego serca i prosza o przebaczenie. Franciszek: List do Przewodniczacego Papieskiej Rady ds. Krzewienia Nowej Ewangelizacji abpa Rino Fisichelli $z$ dnia 1 września 2015. Tekst polski: W: https://w2.vatican.va/content/ francesco/ pl/letters/2015/documents/papa-francesco_20150901_lettera-indulgenza-giubileo-misericordia.html (dostęp: 8.06.2016)

${ }^{64}$ Kongregacja Sakramentów i Kultu Bożego: Obrzędy pokuty. Katowice 2014 s. 195. 


\section{Bibliografia}

Chiappetta L.: Il Codice di Diritto Canonico. Commento giuridico - pastorale. Roma 1996 vol. II. De Paolis V.: Aborto. W: Nuovo dizionario di diritto canonico. Pod redakcja Salvador C.C., De Paolis V., Ghirlanda G. Milano 1996 s. 1-3.

De Paolis V, Cito D: Le sanzioni nella Chiesa. Città del Vaticano 2000.

Erdö P.: Il peccato e il delitto. La relazione tra due concetti fondamentali alla luce del diritto canonico. Milano 2014.

Franciszek: List do Przewodniczacego Papieskiej Rady ds. Krzewienia Nowej Ewangelizacji abpa Rino Fisichelli $z$ dnia 1 września 2015. Tekst polski: W: https://w2.vatican.va/content/frances co/pl/letters/2015/documents/papa-francesco_20150901_lettera-indulgenza-giubileomisericordia.html (dostęp: 8.06.2016).

Gajda P.M.: Sankcje karne w Kościele w świetle Kodeksu Prawa Kanonicznego Jana Pawła II oraz późniejszych zmian i uzupetnień. Studium kanoniczno-pastoralne. Tarnów 2008.

Glemp J.: Dekret $w$ sprawie upoważnienia do rozgrzeszenia z ekskomuniki latae sententiae z kan. 1398. „Wiadomości Archidiecezji Gnieźnieńskiej”. 5-7: 1984 s. 114-115.

Jan Paweł II: Encyklika Evangelium vitae. AAS+. R. 87: 1995. s. 401-522. Ioannes Paulus II: Codex Iuris Canonici. AAS. R. 75 II: 1983.

Jan Paweł II: Kodeks Prawa Kanonicznego. Komentarz. Kraków 2011.

Jaros P.: Prawne aspekty ochrony dziecka przed urodzeniem. W: Aborcja. Przyczyny, następstwa, terapia. Pod redakcja Bogdana Chazana i Witolda Simona. Wrocław 2009 s. 15-22.

Kongregacja Sakramentów i Kultu Bożego: Obrzędy pokuty. Katowice 2014.

Kongregacja Nauki Wiary: Deklaracja o przerywaniu ciązy. AAS. R. 66: 1974 s. 730-747.

Kongregacja Nauki Wiary: Donum vitae. Instrukcja o szacunku dla rodzącego się życia ludzkiego i o godności jego przekazywania (22 lutego 1987). AAS. R. 80: 1988 s. 70-102.

Kowalski J.: Aborcja. W: Encyklopedia bioetyki. Personalizm chrześcijański. Pod redakcja Andrzeja Muszali. Radom 2009 s. 53-59.

Martinelli E.: L'azione penale nell'ordinamento canonico. Uno studio di diritto comparato. Torino 2011.

McNamara E.: La facoltà di assolvere dalle censure. W: https://it.zenit.org/articles/la-facolta-diassolvere-dalle-censure/ (dostęp: 11.06.2016).

Milani D.: L'inizio della vita nel diritto canonico. W: Intorno alla vita che nasce. Diritto ebraico, canonico e islamico a confronto. Pod redakcja D. Atighetchi, D. Milani, A. M. Rabello. Torino 2013 s. $105-192$.

Pontificia Commissio Codicis Iuris Canonici Authentice Interpretando: Odpowiedź zatwierdzona przez Papieża Jana Pawła II dnia 23 maja 1988 roku. AAS. R. 80: 1988 s. 1818-1819.

Sanchis J.: L'aborto procurato: aspetti canonistici. „Ius Ecclesiae”. 2: 1989 s. 663-677.

Sobór Watykański II: Gaudium et spes, Konstytucja duszpasterska o Kościele w świecie współczesnym (7 grudnia 1965). AAS. 58: 1966 s. 1025-1115.

Stokłosa M.: Uwolnienie z kar kościelnych w sakramencie pokuty. „Studia Redemptorystowskie”. $2011 \mathrm{nr} 9-10$ s. 335-358.

Syryjczyk J.: Kanoniczne prawo karne. Część szczególna. Warszawa 2003.

Syryjczyk J.: Kara ekskomuniki a petna wspólnota kościelna wedtug Kodeksu Prawa Kanonicznego z 1983 r. „Prawo kanoniczne”. 33: 1990 nr 3-4 s. 173-196.

Syryjczyk J.: Sankcje w Kościele: część ogólna. Komentarz. Warszawa 2008. 


\section{STRESZCZENIE}

\section{Aborcja w perspektywie kanonicznoprawnej. Zaciągnięcie i zwolnienie z ekskomuniki}

Artykuł prezentuje przestępstwo aborcji w kanonicznym porządku prawnym. Niewątpliwie należy ono do kategorii najcięższych przestępstw przeciwko życiu, albowiem Kościół katolicki stoi na stanowisku nienaruszalności prawa do życia każdego człowieka od chwili jego poczęcia. Naruszenie tego prawa pociąga za sobą sankcje karne, którym podlegają ochrzczeni w Kościele katolickim lub do niego przyjęci, którzy dopuścili się przestępstwa aborcji i trwają w uporze. W momencie przerwania ciąży dochodzi do zaciągnięcia kary ekskomuniki wiążącej mocą samego prawa. Kara tego typu wyłącza wiernego i jego wspólników z możliwości przyjmowania wszystkich sakramentów. Pomimo to, w pewnych okolicznościach ustawodawca przewiduje złagodzenie lub zwolnienie z tejże kary. Wierny który zaciągnął powyższą ekskomunikę może ubiegać się o zwolnienie $\mathrm{z}$ kary zanim otrzyma rozgrzeszenie $\mathrm{w}$ sakramencie pokuty i pojednania.

Słowa kluczowe: aborcja, przerwanie ciąży, prawo do życia, ekskomunika, sankcje karne.

\section{SUMMARY}

\section{Abortion in the Canonical Legal Perspective. Application and Removal of Excommunication}

The article presents the crime of abortion in the canonical legal order. Abortion undoubtedly ranks among the gravest crimes against life as the Catholic Church maintains that each human being has the inviolable right to life from the very moment of conception. Violating this right entails criminal sanctions imposed upon those who were baptized or received in the Catholic Church and who committed the crime of abortion and remain obstinate. At the moment of aborting pregnancy, the penalty of legally-binding excommunication is applied. This type of penalty excludes the faithful and his/her partners from the possibility of receiving all the sacraments. Despite this fact, there are circumstances under which the legislator provides for the mitigation or lifting of this penalty. The excommunicated faithful may apply for the removal of the penalty before he/she receives absolution in the sacrament of Penance and Reconciliation.

Keywords: abortion, termination of pregnancy, right to life, excommunication, criminal sanctions. 